\title{
Updated OpenStudio (OS) Small Office Prototype Model
}

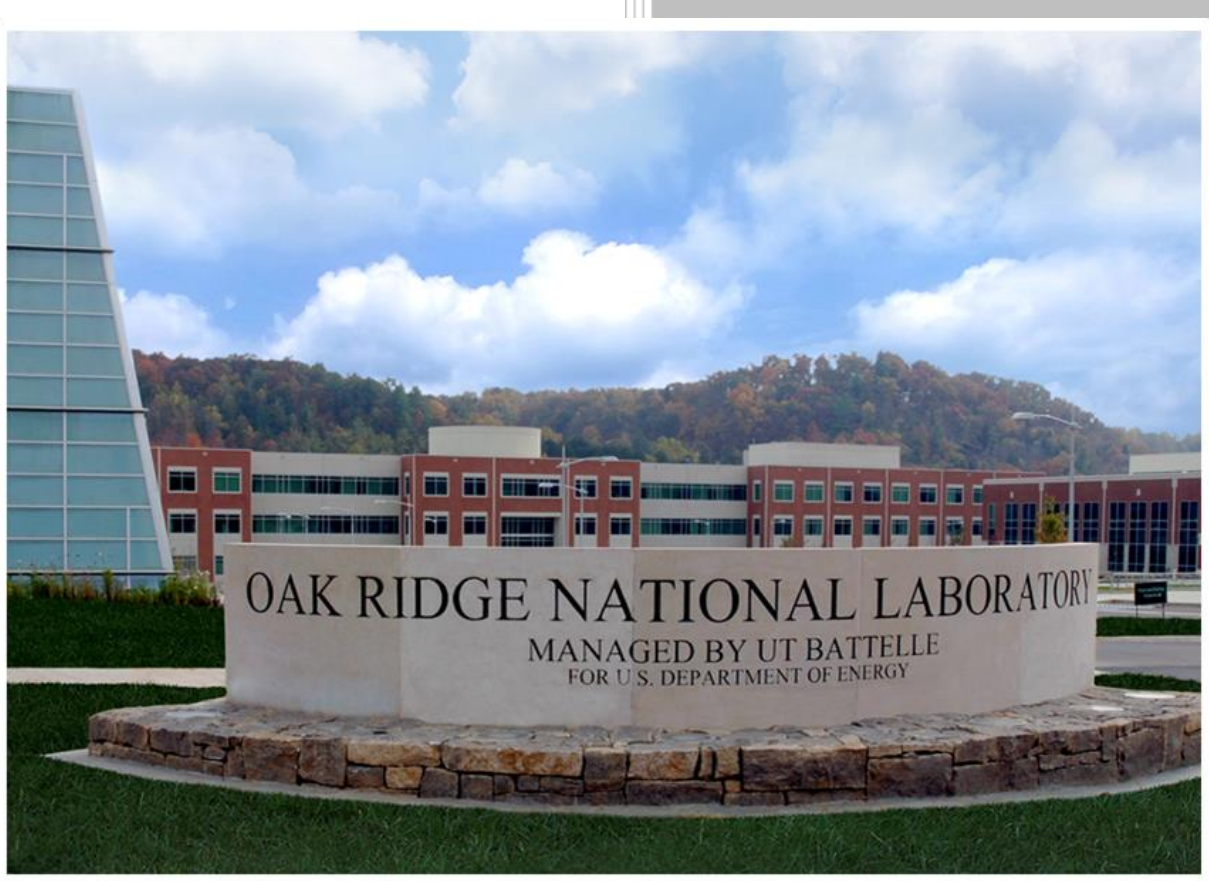

Piljae Im, Ph.D.

Joshua New, Ph.D.

June 30, 2018 


\title{
DOCUMENT AVAILABILITY
}

Reports produced after January 1, 1996, are generally available free via US Department of Energy (DOE) SciTech Connect.

Website http://www.osti.gov/scitech/

Reports produced before January 1, 1996, may be purchased by members of the public from the following source:

\author{
National Technical Information Service \\ 5285 Port Royal Road \\ Springfield, VA 22161 \\ Telephone 703-605-6000 (1-800-553-6847) \\ TDD 703-487-4639 \\ Fax 703-605-6900 \\ E-mail info@ntis.gov \\ Website http://www.ntis.gov/help/ordermethods.aspx
}

Reports are available to DOE employees, DOE contractors, Energy Technology Data Exchange representatives, and International Nuclear Information System representatives from the following source:

Office of Scientific and Technical Information

PO Box 62

Oak Ridge, TN 37831

Telephone 865-576-8401

Fax 865-576-5728

E-mail reports@osti.gov

Website http://www.osti.gov/contact.html

This report was prepared as an account of work sponsored by an agency of the United States Government. Neither the United States Government nor any agency thereof, nor any of their employees, makes any warranty, express or implied, or assumes any legal liability or responsibility for the accuracy, completeness, or usefulness of any information, apparatus, product, or process disclosed, or represents that its use would not infringe privately owned rights. Reference herein to any specific commercial product, process, or service by trade name, trademark, manufacturer, or otherwise, does not necessarily constitute or imply its endorsement, recommendation, or favoring by the United States Government or any agency thereof. The views and opinions of authors expressed herein do not necessarily state or reflect those of the United States Government or any agency thereof. 


\section{Updated OpenStudio (OS) Small Office Prototype Model}

Piljae Im, Ph.D.

Joshua New, Ph.D.

Date Published: June 30, 2018

Prepared by

OAK RIDGE NATIONAL LABORATORY

Oak Ridge, TN 37831-6283

managed by

UT-BATTELLE, LLC

for the

US DEPARTMENT OF ENERGY

under contract DE-AC05-00OR22725 



\section{CONTENTS}

CONTENTS

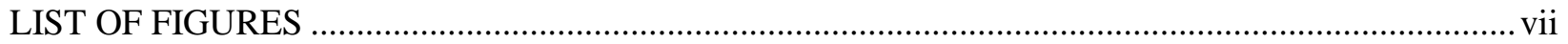

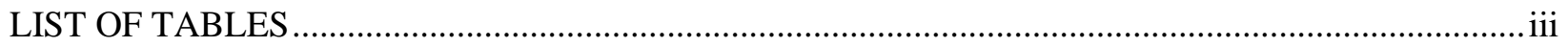

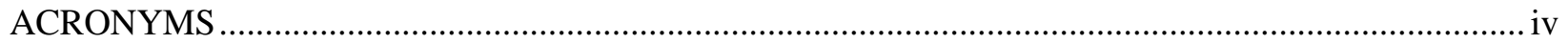

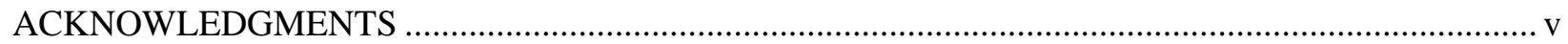

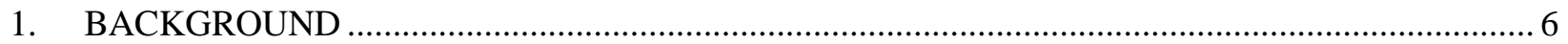

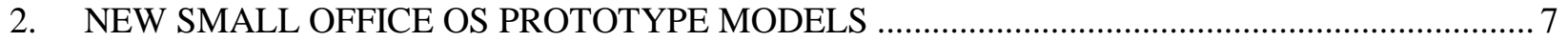

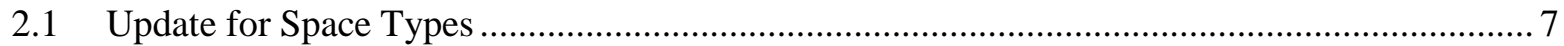

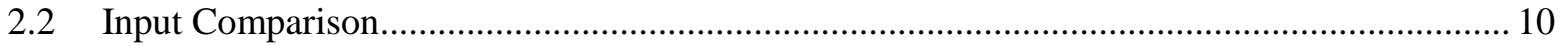

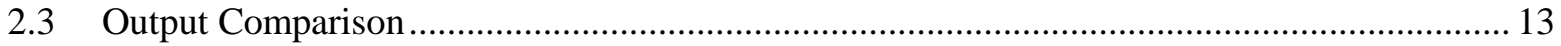

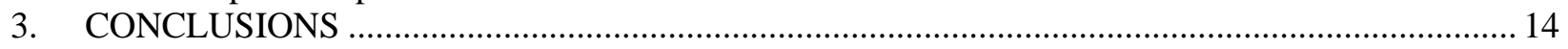

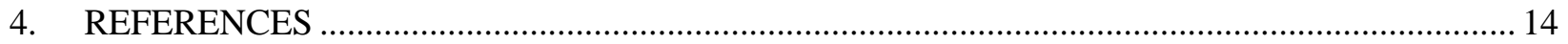





\section{LIST OF FIGURES}

Figure

Page

Figure 1. 3D rendering of the original small office prototype building model ......................................... 7

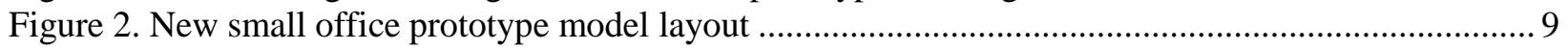

Figure 3. 3D rendering of the new small office prototype building model............................................ 10

Figure 5. Annual energy use comparison between the original OS prototype small office building and the new OS prototype small office building 


\section{LIST OF TABLES}

\section{Table}

Page

Table 1. Space types and area fractions for major zones of the updated small office .............................. 8

Table 2. Lighting, ventilation, occupancy, and elec. equipment per area for ASHRAE 90.1-2004 .......... 11

Table 3. Lighting, ventilation, occupancy, and elec. equipment per area for ASHRAE 90.1-2007 .......... 11

Table 4. Lighting, ventilation, occupancy, and elec. equipment per area for ASHRAE 90.1-2010 .......... 12

Table 5. Lighting, ventilation, occupancy, and elec. equipment per area for ASHRAE 90.1-2013 ........... 12

Table 6. Annual energy use comparison between the original OS prototype small office building and the new OS prototype small office building. 


\section{ACRONYMS}

ANSI American National Standards Institute

ASHRAE American Society of Heating, Refrigerating, and Air-Conditioning Engineers

BEM

DOE

HVAC

IECC

IES

NC3

ORNL

OS OpenStudio Building Energy Modeling

Department of Energy

Heating, Ventilation, and Air Conditioning

International Energy Conservation Code

Illuminating Engineering Society

National Commercial Construction Characteristics

PNNL Pacific Northwest National Laboratory

SSPC Standing Standards Project Committee

VAV Variable Air Volume 


\section{ACKNOWLEDGMENTS}

This material is based upon work supported by the U.S. Department of Energy, Office of Science, and Building Technologies Office. This research used resources of the Oak Ridge National Laboratory Building Technologies Research and Integration (BTRIC), which is a DOE Office of Science User Facility. This work was funded by field work proposal CEBT105 under DOE Building Technology Office Activity Numbers BT0302000 and BT0305000. This manuscript has been authored by UTBattelle, LLC, under Contract Number DEAC05-00OR22725 with DOE. The United States Government retains and the publisher, by accepting the article for publication, acknowledges that the United States Government retains a non-exclusive, paid-up, irrevocable, world-wide license to publish or reproduce the published form of this manuscript, or allow others to do so, for United States Government purposes. 


\section{BACKGROUND}

The U.S. Department of Energy (DOE) supports the development of commercial building energy codes and standards by participating in industry review, update processes, and providing technical analyses to support both published model codes and potential changes. DOE publishes its findings to ensure transparency in its support, and to make its analysis available for both public review and use. In conjunction with this effort, DOE's flagship building energy model (BEM) tools consist of the opensource EnergyPlus simulation engine and OpenStudio. These tools allow a user to modify a building, estimate energy use, and new releases are typically downloaded by over 20,000 users.

As part of DOE's support for ANSI/ASHRAE/IES Standard 90.1 [1] and International Energy Conservation Code (IECC) [2], researchers at Pacific Northwest National Laboratory (PNNL) apply a suite of prototype buildings covering approximately $80 \%$ of the commercial building floor area [3][4] in the United States for new and existing construction, including mid- to high-rise residential buildings, across all U.S. climate zones. These prototype buildings-derived from DOE's Commercial Reference Building Models [5]-cover all Reference Building types (except for supermarkets), and an additional prototype representing high-rise apartment buildings. As Standard 90.1 and IECC are updated every three years, PNNL makes modifications to the commercial prototype building models with extensive input from ASHRAE 90.1 Standing Standards Project Committee (SSPC) members and other building industry experts.

The prototype models include 16 commercial building types in 17 climate locations (across all 8 U.S. climate zones) for recent editions of Standard 90.1 and IECC. The current combination results in an overall set of 2,176 total building models (in EnergyPlus Version 8.0). Of these building types, all three office building types (i.e., Large office, Medium office, and Small office) have only one space type assigned, which is "office" space type. As typical office buildings include many other space types such as conference room, restroom, enclosed office, the office prototype models could not be easily used to properly assess changes (i.e. measures applied) to difference spaces commonly found in an office. As an effort to overcome this limitation, both Large and Medium office prototype building models have been revised to accommodate typical space types found in office buildings [5] [5]. This work has added new space types to the small office, with properties based on Standard 90.1, and compared energy use of this newly-improved small office with that of the original small office. 


\section{NEW SMALL OFFICE OS PROTOTYPE MODELS}

The small office prototype model is one of 16 building types for the prototype models. The small office building model is a 1-story building with $5,500 \mathrm{ft}^{2}(90.8 \mathrm{ft} \times 60.5 \mathrm{ft})$ of conditioned floor area, as shown in Figure 1. The building has four perimeter zones, and one core zone with perimeter zone depth of $16.4 \mathrm{ft}$. The building has also unconditioned attic space. Window-to-wall ratio is approximately $24.4 \%$ for South and $19.8 \%$ for the other tree orientations. The construction of the exterior walls and roof are wood-frame walls, and attic roof with wood joist, respectively. The foundtion type is slab-on-grade. The building HVAC system is air source heat pump systems with gas furnace as back up. The system is constant volume single zone system. Further details regarding the small office prototype building model can be found in [6].

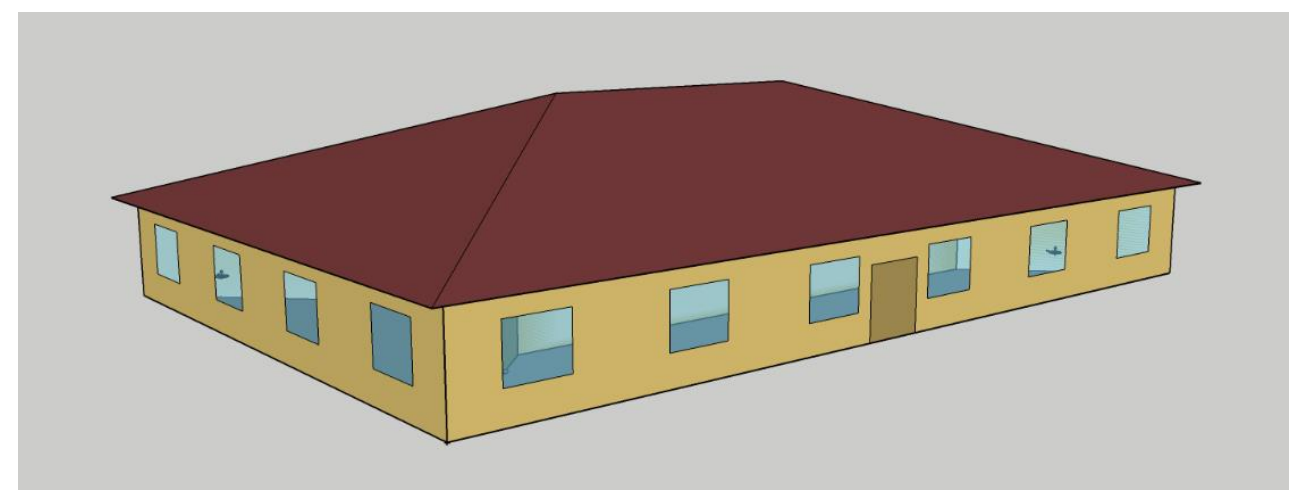

Figure 1.3D rendering of the original small office prototype building model

Although the typical office building contains various space types such as open office, enclosed office, conference room, restroom, and corridor, the existing small office prototype has a uniform space type, which is defined as "office". As the prototype model has this single space type, the lighting power density, plug load, occupancy, ventilation rate, and their schedules are also uniform throughout the entire building. In order to fully utilize OpenStudio Space type measures, the small office prototype model needs to include more detailed space types similar to other prototype building models (e.g. hospital). This document describes the detailed procedure used to update the original small office prototype building model to include various space types, and provides comparative analysis between the original EnergyPlus Prototype model and updated OpenStudio Prototype models in terms of energy use.

\subsection{Update for Space Types}

The original small office prototype was developed based on building characteristics found in National Commercial Construction Characteristics (NC3) database [7]. Originally, the NC3 data set was developed to help provide answers to questions on current commercial design practices, which are important inputs to analyze regarding commercial building energy consumption. The data set is populated with over 130 possible building characteristics for 340 buildings from across the United States. The building characteristics were extracted from sets of real building plans and specifications acquired from the F.W. DODGE Plans Service Division of McGraw Hill. These represent buildings that were in the bid process during the summer of 2001 through the spring of 2007.

Table 1 shows the detailed space type and area fraction for the small office prototype model, which was originally developed by PNNL based on the data from NC3. The updated OS small office prototype 
building model follows the space types and their \% space areas defined in Table 1. Once space types are assigned for the corresponding space area, typical small office building plans [8][9][10] were reviewed to define the new space allocations to the original office model.

Table 1. Space types and area fractions for major zones of the updated small office

\begin{tabular}{|l|l|c|}
\hline $\begin{array}{c}\text { Total Area } \\
\text { (sq.ft) }\end{array}$ & Space & Area Fraction \\
\hline \multirow{3}{5,500}{} & Office open plan & $15 \%$ \\
\cline { 2 - 3 } & Office enclosed & $29 \%$ \\
\cline { 2 - 3 } & Conference/meeting room & $8 \%$ \\
\cline { 2 - 3 } & Corridor/Transition & $12 \%$ \\
\cline { 2 - 3 } & Active Storage area & $14 \%$ \\
\cline { 2 - 3 } & Restrooms & $4 \%$ \\
\cline { 2 - 3 } & Lounge/Recreation area & $2 \%$ \\
\cline { 2 - 3 } & Electrical/Mechanical & $2 \%$ \\
\cline { 2 - 3 } & Stairway & $3 \%$ \\
\cline { 2 - 3 } & Lobby & $5 \%$ \\
\cline { 2 - 3 } & Other & $2 \%$ \\
\hline
\end{tabular}

In this new small office prototype model, building envelope (i.e., wall, roof, and windows) thermal properties and HVAC system type remain the same with the original small office prototype building models. The HVAC system capacity will be auto-sized and therefore may be different from the original model.

The number of occupants, plug load density $\left(\mathrm{W} / \mathrm{ft}^{2}\right)$, lighting power density $\left(\mathrm{W} / \mathrm{ft}^{2}\right)$, and ventilation load are varied based on the space type as defined in ASHRAE Standard 90.1 and 62.1. However, the schedules for occupancy, lighting power, and plug loads remain the same with the original model.

Figure 3 illustrates the new prototype floor layout for the small office building. Figure 3 shows the 3D rendering of the new prototype small office building model. 

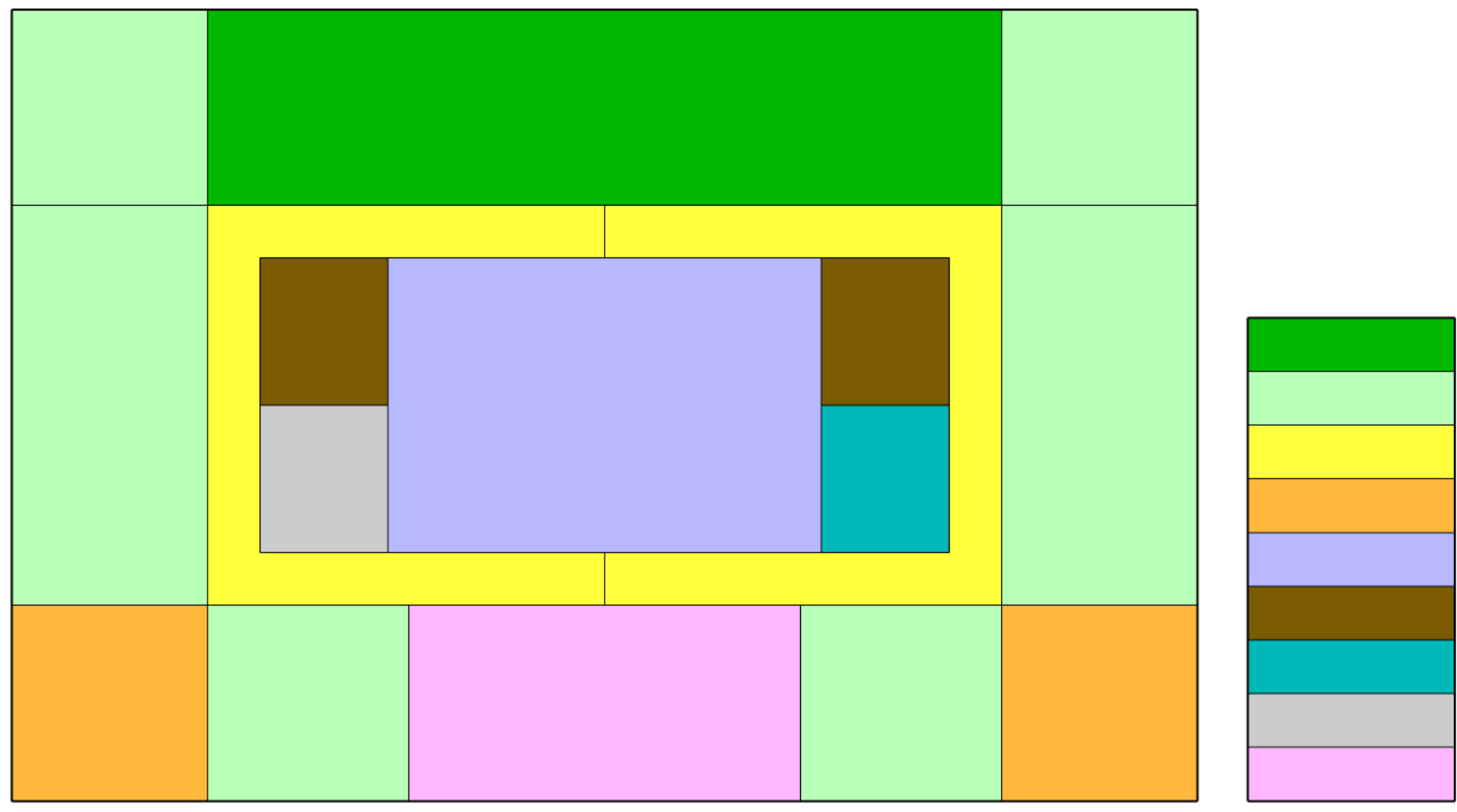

Office - open plan

Office - enclosed

Corridor/Transition

Conference Meeting

Storage

Restrooms

Electrical/Mechanical

Staircase

Lobby

Figure 2. New small office prototype model layout 


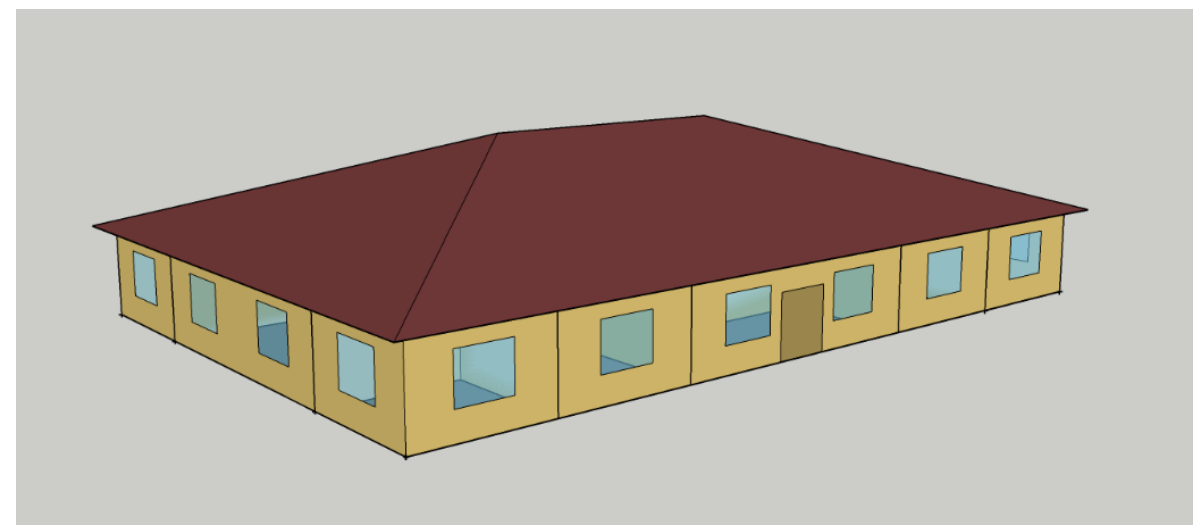

Figure 3. 3D rendering of the new small office prototype building model

\subsection{Input Comparison}

Table 2 -5 compare the input values for the original reference and prototype models and the updated models for different vintages of the ASHRAE 90.1 standard. The variables include lighting power, ventilation rate, occupancy, and electrical equipment power per area. As previously mentioned, the original model has a single uniform space type, office, and there is only one input value per each category. The updated model has various space types, and each space type has different input values based on the definitions from the ASHRAE 90.1[1] and ASHRAE 62.1[11].

The last row of each table shows the area/occupancy weighted average input value for the new prototype building model. It appears, in general, the average input value for the new model is comparable with the original single input value except for the ventilation rate for 2004 vintage (new $0.21 \mathrm{ft}^{3} / \mathrm{min}-\mathrm{ft}^{2} \mathrm{vs}$. original $0.1 \mathrm{ft}^{3} / \mathrm{min}-\mathrm{ft}^{2}$.). Due to largely increased ventilation rate in this vintage, it is expected there would be increased heating energy use specifically for cold climate zones. This will be discussed further in next section - output comparison. 
Table 2. Lighting, ventilation, occupancy, and elec. equipment per area for ASHRAE 90.1-2004

\begin{tabular}{|c|c|c|c|c|c|c|}
\hline Prototype & Space Type & $\begin{array}{l}\text { Lighting } \\
\text { per Area } \\
\left(\mathrm{W} / \mathrm{ft}^{2}\right)\end{array}$ & $\begin{array}{c}\text { Ventilation } \\
\text { per Area } \\
\left(\mathrm{ft}^{3} / \mathrm{min}^{*} \mathrm{ft}^{2}\right)\end{array}$ & $\begin{array}{c}\text { Ventilation per } \\
\text { Person } \\
\text { (ft } \mathrm{ft}^{3} / \mathrm{min}^{*} \text { person) }\end{array}$ & $\begin{array}{c}\text { Occupancy per } \\
\text { Area } \\
\text { (people/1000 } \\
\mathrm{ft}^{2} \text { ) }\end{array}$ & $\begin{array}{c}\text { Electric } \\
\text { Equipment } \\
\text { per Area } \\
\left(\mathrm{W} / \mathrm{ft}^{2}\right)\end{array}$ \\
\hline Original & WholeBuilding - Sm Office & 1 & 0.1 & - & 5.6 & 0.63 \\
\hline \multirow[t]{10}{*}{ Updated } & Storage & 0.8 & 0.15 & 0 & 0 & 0 \\
\hline & Stair & 0.6 & 0.05 & 0 & 0 & 0 \\
\hline & Restroom & 0.9 & 0.05 & 0 & 0 & 0.27 \\
\hline & OpenOffice & 1.1 & 0 & 20 & 5.25 & 0.96 \\
\hline & Lobby & 1.3 & 0 & 15 & 10 & 0.27 \\
\hline & Elec/MechRoom & 1.5 & 0.15 & 0 & 0 & 0.27 \\
\hline & Corridor & 0.5 & 0.05 & 0 & 0 & 0.29 \\
\hline & Conference & 1.3 & 0 & 20 & 50 & 1 \\
\hline & ClosedOffice & 1.1 & 0 & 20 & 4.75 & 0.87 \\
\hline & Weighted Average & 1.01 & 0.21 & - & 7.36 & 0.60 \\
\hline
\end{tabular}

Table 3. Lighting, ventilation, occupancy, and elec. equipment per area for ASHRAE 90.1-2007

\begin{tabular}{|c|c|c|c|c|c|c|}
\hline Prototype & Space Type & $\begin{array}{l}\text { Lighting } \\
\text { per Area } \\
\left(\mathrm{W} / \mathrm{ft}^{2}\right)\end{array}$ & $\begin{array}{c}\text { Ventilation } \\
\text { per Area } \\
\left(\mathrm{ft}^{3} / \mathrm{min}^{*} \mathrm{ft}^{2}\right)\end{array}$ & $\begin{array}{l}\text { Ventilation per } \\
\text { Person } \\
\text { ( } \mathrm{ft}^{3} / \mathrm{min}^{*} \text { person) }\end{array}$ & $\begin{array}{l}\text { Occupancy per } \\
\text { Area } \\
(\text { people/1000 } \\
\left.\mathrm{ft}^{2}\right)\end{array}$ & $\begin{array}{l}\text { Electric } \\
\text { Equipment } \\
\text { per Area } \\
\left(\mathrm{W} / \mathrm{ft}^{2}\right)\end{array}$ \\
\hline Original & WholeBuilding - Sm Office & 1 & 0.1 & - & 5.6 & 0.63 \\
\hline \multirow[t]{10}{*}{ Updated } & Storage & 0.8 & 0.12 & & 0 & 0 \\
\hline & Stair & 0.6 & 0.06 & & 0 & 0 \\
\hline & Restroom & 0.9 & 0.06 & & 0 & 0.27 \\
\hline & OpenOffice & 1.1 & 0.06 & 5 & 5.25 & 0.96 \\
\hline & Lobby & 1.3 & 0.06 & 5 & 10 & 0.27 \\
\hline & Elec/MechRoom & 1.5 & 0.12 & & 0 & 0.27 \\
\hline & Corridor & 0.5 & 0.06 & & 0 & 0.29 \\
\hline & Conference & 1.3 & 0.06 & 5 & 50 & 1 \\
\hline & ClosedOffice & 1.1 & 0.06 & 5 & 4.75 & 0.87 \\
\hline & Weighted Average & 1.01 & 0.11 & - & 7.36 & 0.60 \\
\hline
\end{tabular}


Table 4. Lighting, ventilation, occupancy, and elec. equipment per area for ASHRAE 90.1-2010

\begin{tabular}{|c|c|c|c|c|c|c|}
\hline Prototype & Space Type & $\begin{array}{l}\text { Lighting } \\
\text { per Area } \\
\left(\mathrm{W} / \mathrm{ft}^{2}\right)\end{array}$ & $\begin{array}{c}\text { Ventilation } \\
\text { per Area } \\
\left(\mathrm{ft}^{3} / \mathrm{min}^{*} \mathrm{ft}^{2}\right)\end{array}$ & $\begin{array}{c}\text { Ventilation per } \\
\text { Person } \\
\text { (ft } \mathrm{ft}^{3} / \mathrm{min}^{*} \text { person) }\end{array}$ & $\begin{array}{c}\text { Occupancy per } \\
\text { Area } \\
\text { (people/1000 } \\
\mathrm{ft}^{2} \text { ) }\end{array}$ & $\begin{array}{c}\text { Electric } \\
\text { Equipment } \\
\text { per Area } \\
\left(\mathrm{W} / \mathrm{ft}^{2}\right)\end{array}$ \\
\hline Original & WholeBuilding - Sm Office & 0.9 & 0.085 & - & 5.6 & 0.63 \\
\hline \multirow[t]{10}{*}{ Updated } & Storage & 0.63 & 0.12 & & 0 & 0 \\
\hline & Stair & 0.69 & 0.06 & & 0 & 0 \\
\hline & Restroom & 0.98 & 0.06 & & 0 & 0.27 \\
\hline & OpenOffice & 0.98 & 0.06 & 5 & 5.25 & 0.96 \\
\hline & Lobby & 0.9 & 0.06 & 5 & 10 & 0.27 \\
\hline & Elec/MechRoom & 0.95 & 0.12 & & 0 & 0.27 \\
\hline & Corridor & 0.66 & 0.06 & & 0 & 0.29 \\
\hline & Conference & 1.23 & 0.06 & 5 & 50 & 1 \\
\hline & ClosedOffice & 1.11 & 0.06 & 5 & 4.75 & 0.87 \\
\hline & Weighted Average & 0.94 & 0.11 & - & 7.36 & 0.60 \\
\hline
\end{tabular}

Table 5. Lighting, ventilation, occupancy, and elec. equipment per area for ASHRAE 90.1-2013

\begin{tabular}{|c|c|c|c|c|c|c|}
\hline Prototype & Space Type & $\begin{array}{l}\text { Lighting } \\
\text { per Area } \\
\left(\mathrm{W} / \mathrm{ft}^{2}\right)\end{array}$ & $\begin{array}{c}\text { Ventilation } \\
\text { per Area } \\
\left(\mathrm{ft}^{3} / \mathrm{min}^{*} \mathrm{ft}^{2}\right)\end{array}$ & $\begin{array}{l}\text { Ventilation per } \\
\text { Person } \\
\text { ( } \mathrm{ft}^{3} / \mathrm{min}^{*} \text { person) }\end{array}$ & $\begin{array}{l}\text { Occupancy per } \\
\text { Area } \\
\text { (people/1000 } \\
\left.\mathrm{ft}^{2}\right)\end{array}$ & $\begin{array}{c}\text { Electric } \\
\text { Equipment } \\
\text { per Area } \\
\left(\mathrm{W} / \mathrm{ft}^{2}\right)\end{array}$ \\
\hline Original & WholeBuilding - Sm Office & 0.82 & 0.085 & - & 5.6 & 0.63 \\
\hline \multirow[t]{10}{*}{ Updated } & Storage & 0.63 & 0.12 & & 0 & 0 \\
\hline & Stair & 0.69 & 0.06 & & 0 & 0 \\
\hline & Restroom & 0.98 & 0.06 & & 0 & 0.27 \\
\hline & OpenOffice & 0.98 & 0.06 & 5 & 5.25 & 0.96 \\
\hline & Lobby & 0.9 & 0.06 & 5 & 10 & 0.27 \\
\hline & Elec/MechRoom & 0.42 & 0.12 & & 0 & 0.27 \\
\hline & Corridor & 0.66 & 0.06 & & 0 & 0.29 \\
\hline & Conference & 1.23 & 0.06 & 5 & 50 & 1 \\
\hline & ClosedOffice & 1.11 & 0.06 & 5 & 4.75 & 0.87 \\
\hline & Weighted Average & 0.93 & 0.11 & - & 7.36 & 0.60 \\
\hline
\end{tabular}




\subsection{Output Comparison}

In this new prototype model development, there was no attempt to match the energy use for the new prototype building models to the energy use of the original building models. Since the new model has more space types and associated space attributes, the energy use for the new model should be expected to be different. However, we perform an energy use comparison between the new and original prototype building models to ensure reasonable trends and patterns in comparing the small office across climate zones and for different vintages of the ASHRAE 90.1 standard.

Table 6 and Figure 4 compare the annual total energy use for the original OS small office building and the newly developed OS small office building for the selected climate zones and ASHRAE 90.1 vintages. Given the changes in the occupancy density, lighting and plug load, and OA ventilation rates in the new prototype building model, the energy uses for two different models show close agreement. In general, the energy use for the new model is slightly larger than the original.

As discussed previously, the new models for ASHRAE 90.1-2004 show higher energy use in cold climates than the original model. This is mainly caused by increased OA ventilation loads compared to the original model. The percent difference between the two models ranges from $0-10 \%$.

Table 6. Annual energy use comparison between the original OS prototype small office building and the new OS prototype small office building.

\begin{tabular}{|c|c|c|c|c|}
\hline Template & Climate Zone & $\begin{array}{l}\text { Original OS Prototype Model } \\
\text { Total Annual Energy Use } \\
\text { (GJ) }\end{array}$ & $\begin{array}{l}\text { New OS Prototype Model } \\
\text { Total Annual Energy Use } \\
\text { (GJ) }\end{array}$ & $\begin{array}{l}\text { Percent Differences } \\
\text { (\%) }\end{array}$ \\
\hline \multirow[t]{5}{*}{$90.1-2004$} & $2 A$ & 238.35 & 241.9 & $1 \%$ \\
\hline & $3 B$ & 230.88 & 233.86 & $1 \%$ \\
\hline & $4 \mathrm{~A}$ & 237 & 251.42 & $6 \%$ \\
\hline & $5 \mathrm{~A}$ & 257.55 & 279.74 & $9 \%$ \\
\hline & $6 \mathrm{~A}$ & 264.45 & 291.52 & $10 \%$ \\
\hline \multirow[t]{5}{*}{$90.1-2007$} & $2 \mathrm{~A}$ & 229.6 & 229.2 & $0 \%$ \\
\hline & $3 B$ & 221.74 & 222.33 & $0 \%$ \\
\hline & $4 \mathrm{~A}$ & 229.88 & 234.44 & $2 \%$ \\
\hline & $5 \mathrm{~A}$ & 244.06 & 250.93 & $3 \%$ \\
\hline & $6 \mathrm{~A}$ & 249.86 & 256.76 & $3 \%$ \\
\hline \multirow[t]{5}{*}{$90.1-2010$} & $2 \mathrm{~A}$ & 205.29 & 209.37 & $2 \%$ \\
\hline & $3 B$ & 199.22 & 203.59 & $2 \%$ \\
\hline & $4 \mathrm{~A}$ & 205 & 213.52 & $4 \%$ \\
\hline & $5 \mathrm{~A}$ & 217.68 & 229.47 & $5 \%$ \\
\hline & $6 \mathrm{~A}$ & 222.55 & 235.35 & $6 \%$ \\
\hline \multirow[t]{5}{*}{ 90.1-2013 } & $2 A$ & 174.17 & 177.66 & $2 \%$ \\
\hline & 3B & 170.51 & 174.54 & $2 \%$ \\
\hline & $4 \mathrm{~A}$ & 174.55 & 184.13 & $5 \%$ \\
\hline & $5 A$ & 187.03 & 200.41 & $7 \%$ \\
\hline & $6 \mathrm{~A}$ & 194.01 & 209.08 & $8 \%$ \\
\hline
\end{tabular}




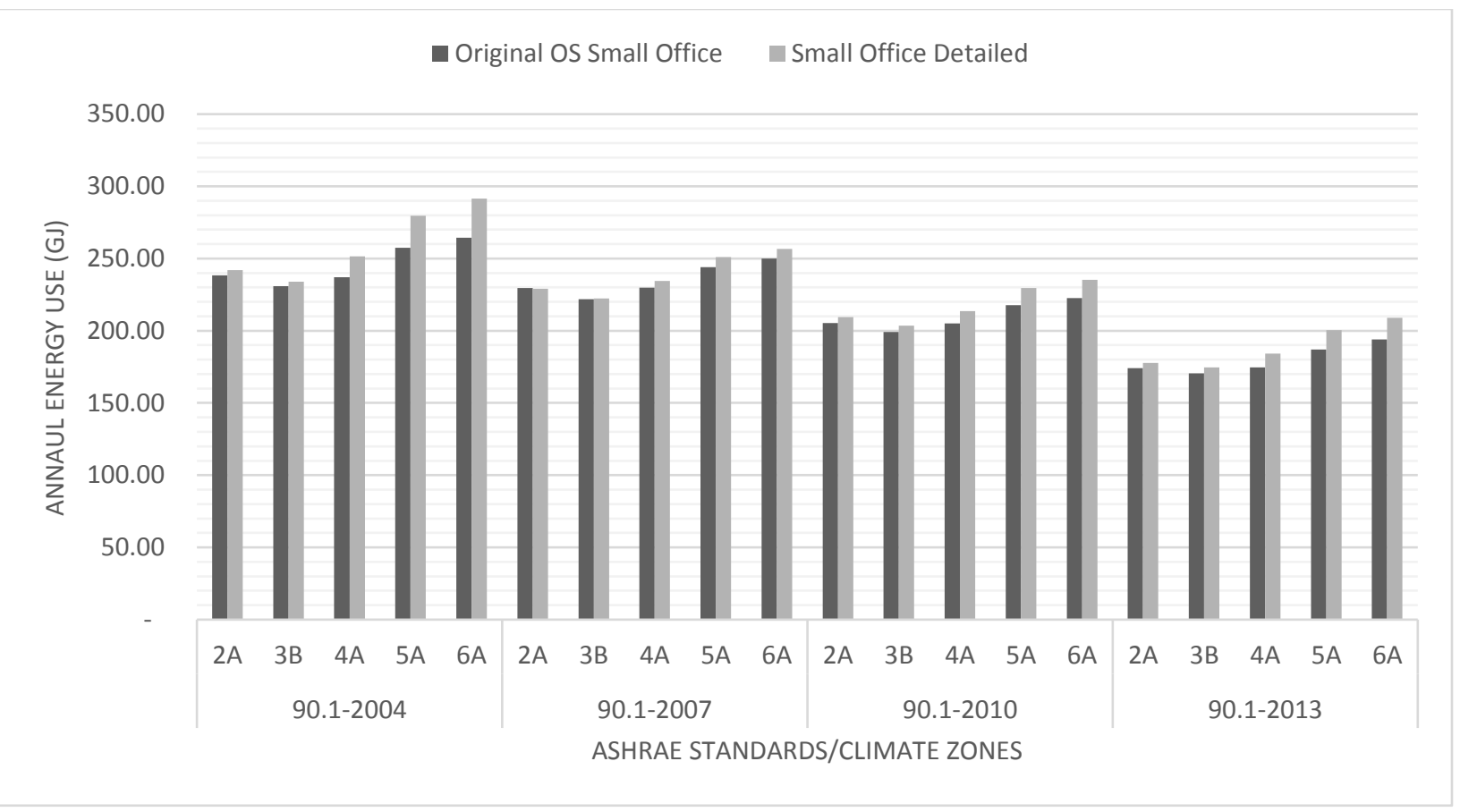

Figure 4. Annual energy use comparison between the original OS prototype small office building and the new OS prototype small office building.

\section{CONCLUSIONS}

This work has updated the small office prototype model with inclusion of new space types based on definitions in existing standards. This updated small office is provided in OpenStudio which will be compatible with all future versions of EnergyPlus and allow application of Space measures to modify a building energy model of a small office.

\section{REFERENCES}

[1] ANSI/ASHRAE/IES Standard 90.1-2016. "Energy Standard for Buildings Except Low-Rise Residential Buildings.” Available WwW: https://www.ashrae.org/resources--publications/bookstore/standard-90-1

[2] International Code Council. "2015 International Energy Conservation Code (IECC)." Available WWW: http://codes.iccsafe.org/app/book/toc/2015/I-Codes/2015\%20IECC\%20HTML/index.html

[3] PNNL 2013. "Commercial Prototype Building Models.” Available WWW: https://www.energycodes.gov/development/commercial/prototype models

[4] Goel, S., Athalye, R., Wang, W., Zhang J., Rosenberg, M., Xie, Y., Hart, R., Mendon, V. 2014. "Enhancements to ASHRAE Standard 90.1 Prototype Building Models," PNNL-23269. Available WWW: https://www.energycodes.gov/sites/default/files/documents/PrototypeModelEnhancements_2014_0.pdf

[5] Deru, M., Field K., Studer, D., Benne, K., Griffith, B., Tocellini, P., Liu, B., Halverson, M., Winiarski, D., Yazdanian, M., Huang, J., and Crawley, D. 2011. "U.S. Department of Energy Commercial Reference Building Models of the National Building Stock," NREL/TP-5500-46861. Available WWW: http://www.nrel.gov/docs/fy11osti/46861.pdf

[6] https://www.energycodes.gov/development/commercial/prototype_models 
[7] Richman, E., Rauch, E., Phillips, J., Petty, K., Knappek J., Lopez-Rangel P. 2008. "National Commercial Construction Characteristics and Compliance with Building Energy Codes: 19992007," 2008 ACEEE Summer Study on Energy Efficiency in Buildings, pp. 291-306. Available WWW: http://aceee.org/files/proceedings/2008/data/papers/3_250.pdf

[8] Chiara, J., and M. Crosbie Time-Saver Standards For Building Types, Fourth Edition, McGrawHill, New York, NY.

[9] https://www.wbdg.org/FFC/GSA/gsa_usc_shell_office.pdf

[10] https://www.gsa.gov/cdnstatic/Circulation - Defining and Planning \%28May 2012\%29.pdf

[11] ANSI/ASHRAE/IES Standard 62.1-2016. "Ventilation for Acceptable Indoor Air Quality" 